\title{
Stereological estimation of structural change in floc matrix following weak ultrasonication
}

\author{
Yuan Ma ${ }^{\mathrm{a}, 1}$, Xiao-Feng Peng ${ }^{\mathrm{a}, 2}$, Duu-Jong Lee ${ }^{\mathrm{b}, 3, *}$ \\ ${ }^{a}$ Laboratory of Phase Change \& Interfacial Transport Phenomena, Tsinghua University, Beijing 100084, China \\ ${ }^{\mathrm{b}}$ Department of Chemical Engineering, National Taiwan University, Taipei 10617, Taiwan
}

Received 20 March 2007; accepted 25 April 2007

\begin{abstract}
Ultrasonication is an energy intensive process used to enhance organics' solubilisation and used in promoting methane yield from wastewater sludge. Applying limited ultrasound without full disruption of floc structure or cell walls can significantly enhance methane yield from sludge at reduced energy cost. This work probed the spatial distribution of extracellular polymeric substances, cells in the original wastewater flocs, and the yielded fragments following weak ultrasonication using a process of multiple staining and a confocal laser scanning microscope technique. The stereological information of the three-dimensional architecture of the original wastewater floc and ultrasonicated fragments was extracted and compared. The local structural changes following weak ultrasonication were presented for the first time, which should also correlate with the enhanced methanogenesis thereby produced.
\end{abstract}

(C) 2007 Taiwan Institute of Chemical Engineers. Published by Elsevier B.V. All rights reserved.

Keywords: Ultrasonication; Floc; Pre-treatment methods

\section{Introduction}

Anaerobic digestion is a very slow process due to the rate limiting step of hydrolysis (Neis et al., 2000). Numerous pretreatments have been reported to promote hydrolysis and to disintegrate sludge flocs, thereby enhancing the efficiency of the subsequent anaerobic digestion stage (Lee and Mueller, 2001; Mukherjee and Levine, 1992). Numerous methods have also been used to break up cell membranes in bioprocesses (Bougrier et al., 2006; Hwang et al., 2006; Kao et al., 2006; Lai et al., 2006; Liao, 2006; Show et al., 2006; Tao et al., 2006; Thongchul and Yang, 2006; Zhang et al., 2007). Chu et al. (2001), along with Lee and Mueller (2001), commented on the application of pre-treatments to improve the biodegradability of sludge. High-power ultrasound at low frequencies could generate intensive cavitation which would result in sludge disintegration and the release of intracellular materials (Neis et al., 2000). Show et al. (2006) experimentally proved that a

\footnotetext{
* Corresponding author. Tel.: +886 2 23625632; fax: +886 223623040.

E-mail address: djlee@ntu.edu.tw (D.-J. Lee).

1 馬 淵

2 彭曉峰

3 李篤中
}

sonication treatment could improve the sludge properties in terms of soluble chemical oxygen demand (SCOD) increase and particle size reduction. Compared with other pre-treatment methods, i.e., thermal treatment, ozone treatment, chemical treatment, etc., ultrasonication exhibits great potential of being less hazardous to the environment (Tiehm et al., 1997, 2001).

Ultrasonication, however, requires a considerable amount of energy during treatment. Chu et al. (2002) examined how "weak" ultrasonic pre-treatment affects the anaerobic digestion of waste biosolids. The ultrasound applied was insufficient to fully disrupt the floc structure or the cell walls, but was still able to significantly enhance methane yield from biomass at reduced energy cost (Ding et al., 2006). These authors claimed that, with gross structure intact, weak ultrasonication loosened the local structure of the floc matrix and created active sites for easy attack by microbes, hence producing an increased amount of methane. Up to the present, though, there exists no detailed study on how insufficient ultrasound on sludge flocs can enhance a subsequent methanogenesis process.

Extracellular polymeric substances (EPS) and cells form the bioaggregates, such as biofilm, sludge flocs, river snow, and others. Chen et al. (2007) demonstrated the distribution of EPS (proteins, $\alpha$ - and $\beta$-polysaccharides, and lipids) and cells in aerobic granules using a newly proposed multiple staining 
scheme and a confocal laser scanning microscope (CLSM) technique. This work probed the spatial distribution of EPS and cells in the original wastewater flocs and the yielded fragments following weak ultrasonication. With the stereological information collected in the scanned images, the authors of this research proved experimentally weak ultrasonication do yield local structural changes with gross architecture intact.

\section{Experimental}

\subsection{Samples}

Waste activated sludge was extracted from a wastewater treatment plant of the Presidental Enterprise Corp., Taiwan, which daily treats 250 tonnes of food-processing wastewater using primary, secondary, and tertiary treatments. The $\mathrm{pH}$ of the sludge was about 6.4. The chemical oxygen demand (COD) for the sludge was $9600 \mathrm{mg} / \mathrm{L}$ (TCOD), as determined by directly reading a spectrometer (DR/2000, HACH, U.S.A.). The elemental composition of the dried samples was C: $34.3 \%$, $\mathrm{H}: 5.6 \%$ and $\mathrm{N}: 5.5 \%$, according to an elemental analyzer (Perkin-Elmer, $2400 \mathrm{CHN}$ ).

\subsection{Floc staining and CLSM test}

In each test, one floc was carefully collected from the sample suspension with a wide-mouthed pipette. The collected floc was maintained in a fully hydrated state during staining. During staining, SYTO 63 (Molecular Probes, Carlsbad, CA, U.S.A.) solution $(20 \mu \mathrm{M}, 100 \mu \mathrm{L})$ was first added to the sample and the sample was placed on a shaker table for $30 \mathrm{~min}$. Next, $0.1 \mathrm{M}$ sodium bicarbonate buffer $(100 \mu \mathrm{L})$ was added to retain the amine group in a non-protonated form, which was followed by a fluorescein isothiocyanate (FITC) (Molecular Probes, Carlsbad, CA, U.S.A.) solution (10 g/L, $10 \mu \mathrm{L})$, and the mixture was stirred at room temperature for $1 \mathrm{~h}$. Subsequently, the fluorescently labeled lectin, concanavalin A (Con A) (Molecular Probes, Carlsbad, CA, U.S.A.), was conjugated with a tetramethylrhodamine solution $(250 \mathrm{mg} / \mathrm{L}, 100 \mu \mathrm{L})$ and incubated with the sample for an additional $30 \mathrm{~min}$, followed successively by the addition of calcofluor white (fluorescent brightener 28, Sigma,
U.S.A.) solution (300 mg/L, $100 \mu \mathrm{L})$ for $30 \mathrm{~min}$. Following each of these five staining stages, the stained sample was washed twice with phosphate-buffered saline ( $\mathrm{pH}$ 7.2) to remove excess stain, and the stained sample was stored at $4{ }^{\circ} \mathrm{C}$. The stained flocs were then embedded for cryosectioning and frozen at $-20^{\circ} \mathrm{C}$, after which $60 \mu \mathrm{m}$ sections were cut on a cryomicrotome and mounted onto microscopic slides for analysis.

Confocal laser scanning microscopy (CLSM) (Leica TCS SP2 Confocal Spectral Microscope Imaging System, Gmbh, Germany) was employed to visualize the distribution of cells and extracellular polymeric substances in the flocs. The flocs were imaged with a $10 \times$ or $20 \times$ objective and analyzed using Leica confocal software.

\subsection{Ultrasonication test}

After the CLSM test, the stained floc was transferred to a $200 \mathrm{~mL}$ vessel containing supernate of the sludge sample. Low frequency ultrasound was applied at an intensity of $56 \mathrm{~W} \mathrm{~cm}^{-2}$ for $2 \mathrm{~s}$ to disrupt the floc. As Chu et al. (2002) observed, the total energy input for the applied ultrasound was far from sufficient to completely disrupt the flocs and to release all soluble matters from sludge matrix.

Following ultrasonication, the floc was commonly disrupted into a few fragments. The fragments were carefully collected and then were tested again using CLSM, as stated above. A total of four sludge flocs were tested and analyzed.

\section{Results and discussion}

\subsection{Floc disruption}

Fig. 1(a) shows the fluorescent staining results probed at $360 \mu \mathrm{m}$ from the outer surface of floc \#1. The floc has a roundshaped structure. According to the fluorescent intensity data presented in the figure, the protein was distributed over the entire floc. Lipids and $\beta$-polysaccharides were also distributed over the floc, but in a lower quantity. The cells (in red) and the $\alpha$-polysaccharides (in light blue) were allocated most at the floc core area. The image shown in the lower-right corner was the combined image of the five individual stains.
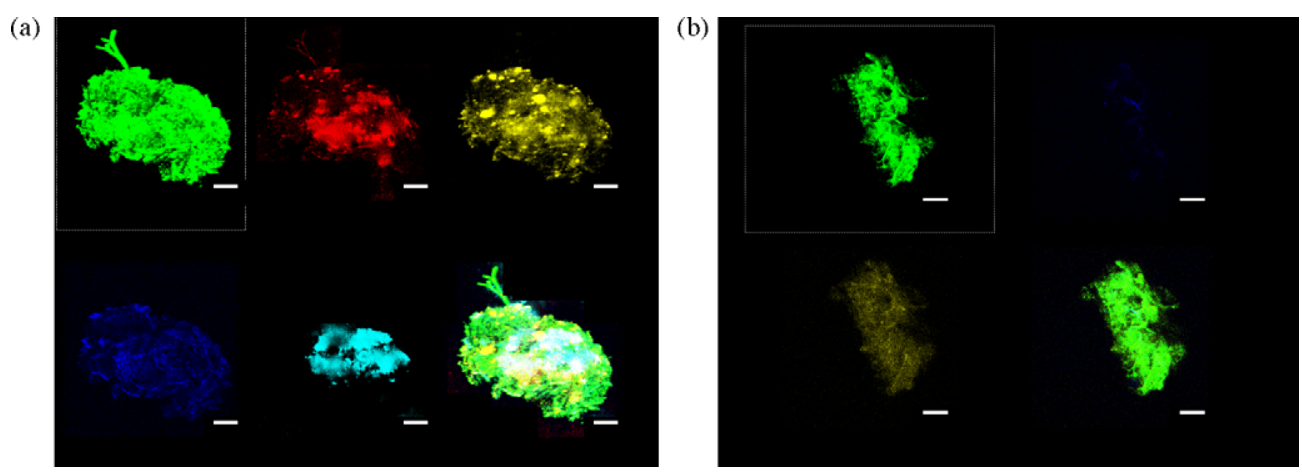

Fig. 1. Fluorescent images of sludge floc. Green: proteins; red: cells; yellow: lipids; blue: $\beta$-polysaccharides; light blue: $\alpha$-polysaccharides. Combined image: rightbottom corner. (a) Original floc \#1; (b) fragment collected following ultrasonication (For interpretation of the references to colour in this figure legend, the reader is referred to the web version of the article.) 


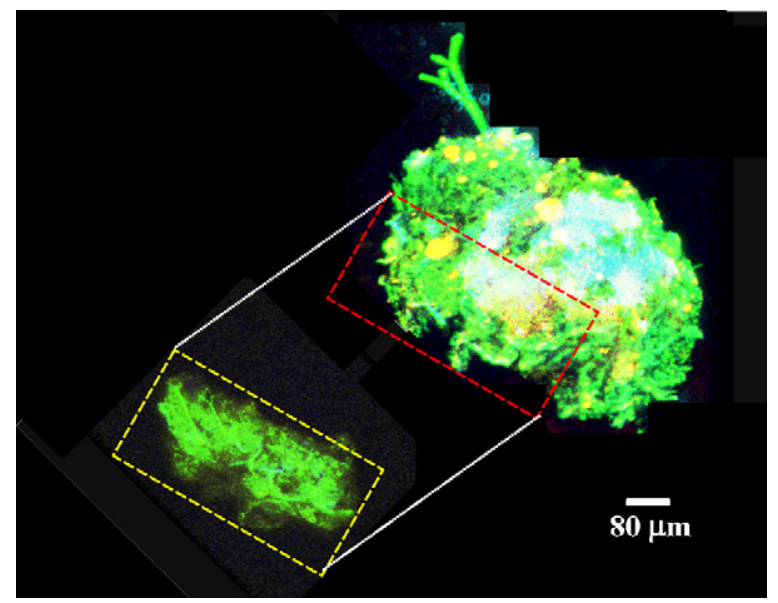

Fig. 2. Combined fluorescent images of sludge floc and the yielded fragment.

Fig. 1(b) shows the fluorescent staining results probed at $360 \mu \mathrm{m}$ from the outer surface of a fragment from floc \#1. This fragment was located in the outer rim of floc \#1, hence, was lacking cells and $\alpha$-polysaccharide (Fig. 1(a)). However, the intensities of proteins and lipids were clearly probed, with most of the $\beta$-polysaccharide being lost in the fragment images. Restated, the present result contradicts those reported by Wang et al. (2006a,b) that the main component released from the sludge matrix in ultrasonication was protein. Chen et al. (2007) noted that the $\beta$-polysaccharides were the main backbone for microbial aggregates such as aerobic granules. The removal of $\beta$-polysaccharide could significantly weaken the wastewater floc, hence yielding subsequent disintegration of structure under an ultrasonic field.

Based on the geometrical features of the original floc and the fragments, the disruption process is shown schematically in Fig. 2.

\subsection{Structural change}

The local architecture of the sampled flocs was quantified using the stereological method (Reed and Howard, 1999). First, the pixels of each fluorescent image for proteins, $\alpha$-and $\beta$ polysaccharides, lipids, or cells were bileveled using Otsu's method, then the pair cross-correlation functions, $g(r)$, for each pair were evaluated. With $g(r)>1$, the two substances were spa-tially attracting; while with $g(r)<1$, they were spatially repulsing.

Fig. 3 shows some $g(r)$ functions enveloped with their $95 \%$ confidence intervals for the original flocs and their ultrasonicated fragments. All the $g(r)$ functions for original flocs revealed a mono-dispersed characteristic and peaked at around $2-10 \mu \mathrm{m}$ in distance, indicating that the probed substances were largely associated with cell membranes and the peak was
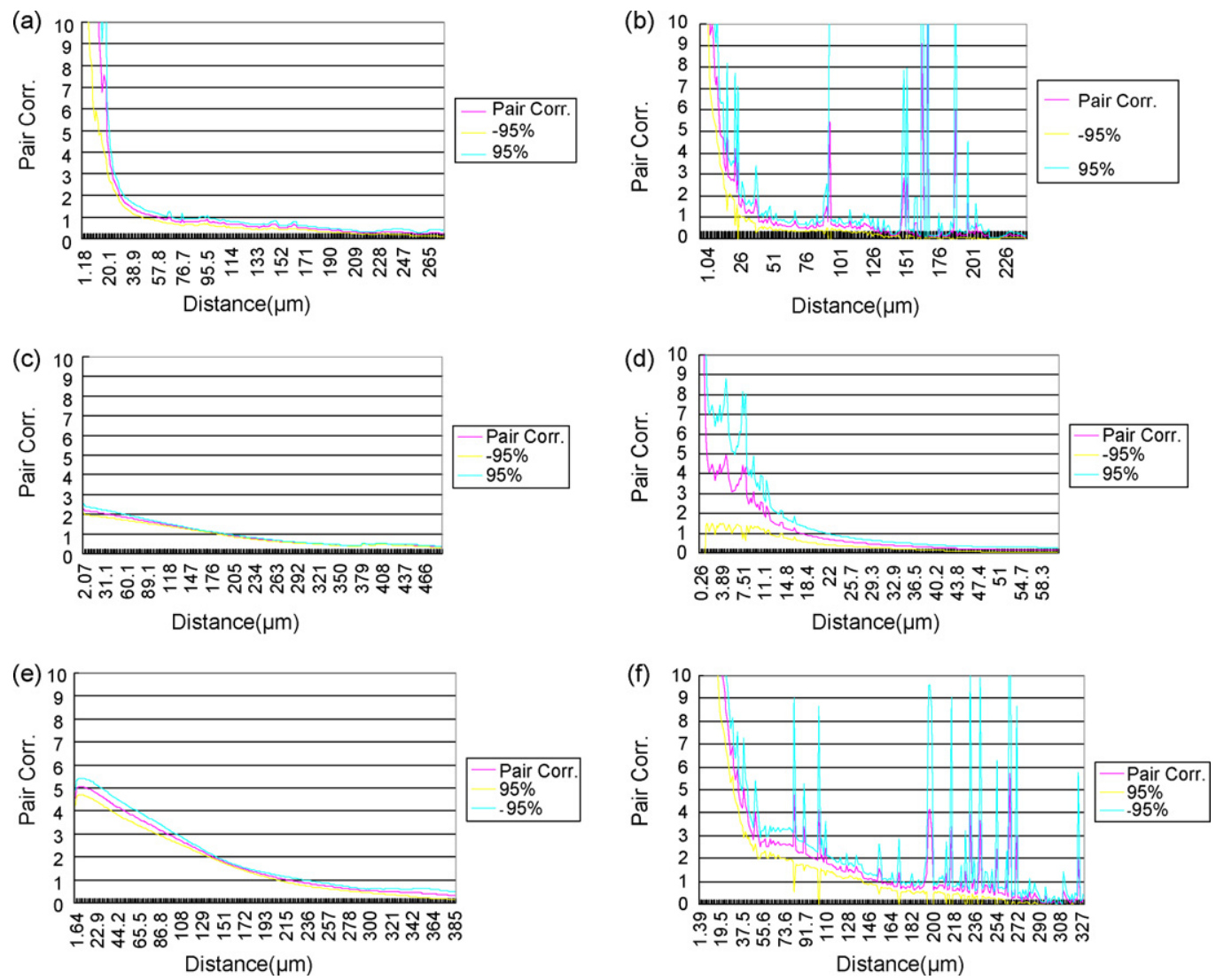

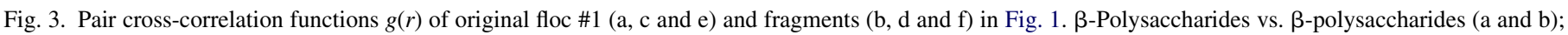
proteins vs. proteins (c and d); and lipids vs. $\alpha$-polysaccharides (e and f). 
correspondent to the distance between neighboring cells. Following ultrasonication, numerous minor peaks emerged on the $g(r)$ function over a wide range of distance, indicating disturbance of local architecture. However, the main peak of $g(r)$ remained unchanged, revealing that the gross structure of floc matrix had not deteriorated.

Hence, the present work for the first time proved that the application of weak ultrasound did yield changes in local structure, correlating with the hypothesis proposed by Chu et al. (2002). Apparently this change as well as the noted release of $\beta$-polysaccharides correspond to the enhanced methanogenesis reported in Chu et al. (2002) and Ding et al. (2006), and are probably attributable to the reduced internal mass transfer resistances of the fragments.

\section{Conclusion}

Applying ultrasound that is insufficient to fully disrupt floc structure or cell walls can significantly enhance the methane production yield from biomass. This work measured the spatial distribution of EPS and cells in individual wastewater flocs and their yielded fragments following weak ultrasonication, using a multiple staining and CLSM technique. The stereological information on how the EPS and cells are distributed in floc matrix was utilized to identify the corresponding local structural changes before and after weak ultrasonication.

Following ultrasonication, the $\beta$-polysaccharides were significantly lost from the floc matrix, probably correlating with the disruption of gross floc matrix under shear. The pair cross-correlation functions of the probed EPS and cells in the floc matrix had a mono-dispersed characteristic and peaked at around $2-10 \mu \mathrm{m}$ in distance. Following weak ultrasonication, the gross architecture of the floc matrix remained intact, but the disturbances to the local architecture were probed by the reconstructed pair cross-correlation functions. Enhanced methane production from weakly ultrasonicated sludge may be attributable to the reduced interior mass transfer resistances associated with the noted disturbed structure by ultrasound.

\section{References}

Bougrier, C., C. Albasi, J. P. Delgenes, and H. Carrere, "Effect of Ultrasonic, Thermal and Ozone Pre-treatments on Waste Activated Sludge Solubilisation and Anaerobic Biodegradability," Chem. Eng. Proc., 45, 711 (2006).

Chen, M. Y., D. J. Lee, and J. H. Tay, "Distribution of Extracellular Polymeric Substances in Aerobic Granules," Appl. Microbiol. Biotechnol., 73, 1463 (2007).
Chu, C. P., D. J. Lee, B. V. Chang, and C. S. Liao, “Observations on Changes in Ultrasonically Treated Waste Activated Sludge," Water Res., 35, 1038 (2001).

Chu, C. P., D. J. Lee, B. V. Chang, C. S. Liao, and J. H. Tay, ““"Weak” Ultrasonic Pre-treatment on Anaerobic Digestion of Flocculated Activated Sludge," Water Res., 36, 2681 (2002).

Ding, W. C., D. X. Li, X. L. Zeng, and T. R. Long, "Enhancing Excess Sludge Aerobic Digestion with Low Intensity Ultrasound," J. Centr. S. Univ. Technol., 13, 408 (2006).

Hwang, K. J., S. F. You, and T. M. Don, "Disruption Kinetics of Bacterial Cells during Purification of Poly-beta-hydroxyalkanoate Using Ultrasonication,” J. Chin. Inst. Chem. Engrs., 37, 209 (2006).

Kao, P. M., P. Tsai, Y. C. Liu, and Y. C. Chang, "Optimization of Cultivation Conditions for the Production of Chitinase from Paenibacillus sp CHE-N1," J. Chin. Inst. Chem. Engrs., 37, 355 (2006).

Lai, J. T., M. H. Chen, H. Y. Wan, and C. C. Liao, "Recovery of Isoamylase Using an Aqueous Two-Phase System," J. Chin. Inst. Chem. Engrs., 37, 107 (2006).

Lee, D. J. and J. A. Mueller, Preliminary Treatments, In L. Spinosa and A. Vesilind (Eds.), IWA Publishing, London, U.K. (2001).

Liao, J. C., "System Biology: Where Does Chemical Engineering Stand?". $J$. Chin. Inst. Chem. Engrs., 37, 103 (2006).

Mukherjee, S. R. and A. D. Levine, "Chemical Solubilization of Particulate Organics as a Pretreatment Approach,” Water Sci. Technol., 26, 2289 (1992).

Neis, U., K. Nickel, and A. Tiehm, "Enhancement of Anaerobic Sludge Digestion by Ultrasonic Disintegration," Water Sci. Technol., 42, 73 (2000).

Reed, M. G. and C. V. Howard, "Stereological Estimation of Covariance Using Linear Dipole Probes," J. Microscope, 195, 96 (1999).

Show, K. Y., T. H. Mao, J. H. Tay, and D. J. Lee, "Effects of Ultrasound Pretreatment of Sludge on Anaerobic Digestion," J. Residuals Sci. Technol., 3, 51 (2006).

Tao, T., X. F. Peng, and D. J. Lee, "Interaction between Ice and Floc under Freezing," J. Chin. Inst. Chem. Engrs., 37, 299 (2006).

Thongchul, N. and S. T. Yang, "Controlling Biofilm Growth and Lactic Acid Production by Rhizopus oryzae in a Rotating Fibrous Bed Bioreactor: Effects of Dissolved Oxygen, Rotational Speed, and Urea Concentration," J. Chin. Inst. Chem. Engrs., 37, 49 (2006).

Tiehm, A., K. Nickel, and U. Neis, "The Use of Ultrasound to Accelerate the Anaerobic Digestion of Sewage Sludge," Water Sci. Technol., 36, 121 (1997).

Tiehm, A., K. Nickel, M. Zellhorn, and U. Neis, "Ultrasonic Waste Activated Sludge Disintegration for Improving Anaerobic Stabilization," Water Res., 35, 2003 (2001).

Wang, F., M. Ji, and S. Lu, "Influence of Ultrasonic Disintegration on the Dewaterability of Waste Activated Sludge," Environ. Progr., 25, 257 (2006a).

Wang, F., S. Lu, and M. Ji, “Components of Released Liquid from Ultrasonic Waste Activated Sludge Disintegration," Ultrason. Sonochem., 13, 334 (2006b).

Zhang, P. Y., G. M. Zhang, and W. Wang, "Ultrasonic Treatment of Biological Sludge: Floc Disintegration, Cell Lysis and Inactivation," Bioresource Technol., 98, 207 (2007). 


\title{
有限超音波處理下膠羽局部結構改變之空間測量
}

\author{
馬 淵 彭曉峰 \\ 北京清華大學相變與界面輸送實驗室 \\ 李篤中 \\ 國立台灣大學化學工程學系
}

摘 要

超音波程序為增強污泥有機物水解及提昇甲烷產率之耗能程序, 在不破壞膠羽結構及細胞壁之前提下提供有限超音 波能量仍可大幅增加甲烷產率。本研究使用多重染色及同軸共軛焦顯微技術探測膠羽在有限超音波處理前後之胞間高分 子及細胞三維空間分佈，並首次報導有限超音波能量下膠羽局部結構改變之證據。 